\title{
Information and communication technologies and teacher education in the new paradigms of higher education
}

\author{
Mirella Müller \\ Department of Pedagogy, Faculty of Humanities and Social Sciences, \\ University of Osijek \\ mtolic@ffos.hr \\ Ines Begović \\ Student, Department of Pedagogy, Faculty of Humanities and Social \\ Sciences, University of Osijek \\ ines-vk@live.com \\ Ralf Baumgärtner \\ University of Mainz, Institut of Mediaeducation, Germany \\ rbaumgartner45web.de
}

\begin{abstract}
Media use in the teaching process occurs in several forms. Information and communication technologies can be used as work equipment and teaching aids, as well as tools or curriculum units, particularly in higher education. Technological changes and new information technologies, in addition to substantive knowledge of the material, require from teachers creativity, knowledge, and the skills of the didactic design of teaching using modern multimedia tools. In Croatia, there is a lack of research aimed at assessing the initial state of computer literacy within the higher education institutions. The aim of this study was to determine the level of knowledge and digital competence of (non) teachers of higher education institutions in the Republic of Croatia, to determine the frequency of application of modern technologies in teaching, and to explain the necessity of implementation of the programme Multimedia training and e-learning at teaching faculties, which leads to the application of new educational paradigms. The study was conducted on a representative sample $(N=1800)$ of (non) teachers of higher education institutions in the Republic of Croatia among various faculties and departments in Osijek, Split and Zagreb. The results show that (non) teachers of higher education institutions of engineering and information sciences have the best digital competences, and apply modern technology in research and scientific work significantly more than (non) teachers of social sciences and humanities.
\end{abstract}

Keywords: didactic challenges, digital competences, representative sample, survey sampling research, the purpose of the application of new technologies.

JEL classification: I20, 121, 123.

DOI: 10.2478/crebss-2018-0003

Received: March 22, 2018

Accepted: June 14, 2018 


\section{Introduction}

Media competence is a central concept in media pedagogy. It includes all the capabilities that primarily a teacher and / or a student must adopt within mediainformation education. These skills are related to the construction of critical reflection against the challenges of new media. The need for technological skills and knowledge in the school, in the workplace, and generally in all social activities is a consequence of living in a digital environment for which Alvin Toftler coined the term "Information Age" (Farke, 2006). For the teachers to respond to the increasingly numerous and demanding needs of digital or information society, they need to have certain knowledge, skills, and abilities which can help them with an easier implementation of teaching content. Contemporary recent research implicitly indicates the necessity of integrating modern technologies in teaching in the context of improvement of research and teaching work in higher education institutions, particularly those components with teacher training.

With the emergence of new technologies the method of learning is significantly changing. The student no longer receives knowledge by passive listening, but by using different technologies to actively adopt the necessary knowledge. The imperative of contemporary society and schools, with expertise in the professional domains, is certainly creativity, innovation, critical and reflective attitude, metacognitive skills, and motivation to acquire knowledge and skills (Rychen, Salganik, 2000). Since the development of books, radio, television, and electronic media, there is a great discussion by experts how the media contribute to the development of motivation in learning, especially learning certain teaching units in the field of mathematics. Through a variety of digital sources, materials in mathematics can be presented to students in a visually interesting and easier way. The most current skills are available online, one should be able to use them, get continuous further professional improvement, and practically apply them. There is a constant strive to invest into schools and the education system so there are always new educational and teaching technologies in the schools. Students and teachers are often faced with the speed of development of innovative media and with their proper and practical application (Adomeit, 1997).

The didactic-methodic, curricular thinking, and monitoring of current issues and problems of modern teaching are of crucial importance for effective movement towards the planned educational outcomes, that is the acquisition of needed competencies (instrumental, interpersonal, systemic, and specific - subject oriented) (Ashaver, 2004). Teachers are expected to develop among students the knowledge, abilities, skills, critical thinking, which is currently required in the information society, based on the application of information and communication technology. But often, the teachers find themselves in a situation that the students are more computer literate and more likely to use a computer as entertainment, rather than to solve school assignments. The computer offers students a world of countless relevant and irrelevant information which easily distract them from the idea of the purposeful use of the computer.

Accordingly, a pedagogical problem is how to install the computer in the teaching process, as well as how to use computers to assist the teaching process to make it more efficient and more interesting. There is also the question of how new technology is changing the educational paradigms, and whether these changes lead to the development of a functional process or not. ICT, as new tools for teaching, should contribute to the development and application of new educational paradigms which primarily means having knowledge of media-didactic analysis of digital media, which answers the question of the choice of the media to 
facilitate the educational process and motivate students to learn. It is one of the fundamental pragmatic-didactic questions that often troubles primary school teachers and class teachers because the motivation of students to learn is one of the most important objectives of all teachers.

The development of digital media and the level of acquired digital competence is causing teachers often the dilemma of choosing a particular type of media. Choosing the right media for certain subjects can greatly facilitate the transfer of information to the students. Since the beginning of the use of computers in teaching, different models of planning the teaching, changing education paradigms, as well as changes in learning outcomes began to develop. The change of educational paradigms is based on that with the help of technological implications (collaborative software tools and e-mail, computer networks and software tools for education, different approaches to software tools and methods, and the development of skills and digital simulation) which lead to the development of socalled new model of learning which would include: individual research instead of just teaching in the classroom; (self-) education rather than passive absorption; team learning instead of individual work; the teacher would be given the role of a guide adviser instead of the so-called "omniscient teacher"; teaching content that is quickly changing instead of stable content; and diversity rather than homogeneity (Moser, 2007).

\section{Literature review}

Over the past few years, didactics have increased interest in the subject of media using in Higher institution of Croatia. According to the Croatian Education, Science and Technology Strategy, the concept of lifelong learning is based on education and lifelong learning (Jovanović, Zelenika, 2013). Along with the strategic planning of the European Union, the Education, Science and Technology Strategy proposes measures and goals whose achievement is expected until 2025. Among the offered vision of long-term development, it is primarily aimed at encouraging the initiative and creativity of employees as well as future employees in the system, in order to ensure the dignity of future teachers, associates and researchers; in order to facilitate the adaptation of educational and research processes, thus enabling better quality and monitoring the strategic planning of the European Union. As stated in the document of strategic planning of the whole education and research area, it has to survive the triangle of knowledge that consists of education, research and innovation (Jovanović, Zelenika, 2013). It is certainly the first task in realizing the integration and introduction of information-communication technologies into the system, with the aim of developing cultural, social and human capital.

The European Council has already adopted a work program called "Education and Professional Development" in 2002, defining eight key competences for the $21 \mathrm{st}$ century: maternity communication, foreign language communication, mathematical literacy and basic knowledge of science and technology, digital competences, learning competence, interpersonal and civic competences, entrepreneurship and cultural expression (Commission of the European Communities, 2007). The Agency for Vocational Education and Adult Education (ASOOO) under the Erasmus program carries out the project "Digital Competences for Teachers" (an international project with Slovenia, Lithuania, and Turkey) aiming to create a portal that will enable teachers to e-learning and critical use of information-communication technologies for work and better communication (Commission of the European Communities, 2007). Some recommendations were used in the literature as a possible solution in the implementation of ICT in teaching as a new paradigm in 
learning and teaching at the institutions of higher education. Various recommendations have been used: a) Analysis and implemetation of e-learning (use of the media for lifelong learning, connection of digital communication and media taxonomy with databases, table calculations, distance learning communication, elearning programs and tools: programs for acquiring academic titles from natural, and other sciences, programs for further training, retraining, specialization and programs in the field of living culture); B)Methodology and Didactics in E-Learning: Methods of E-Learning / Methods: a) Bleanded Learning, b) Social Learning and Web 3.0 c) Mobile Learning, d) WebQuests and Game Based Learning; C) Didactic basics: a) didactic e-learning models, e-learning web-design, c) e-learning platform, d) multimedia system building, e) multimedia learning techniques and online material development in web technology higher level than ECDL to ECDL CAD (Computer Aided Design) and ECDL CTP (Certified Training Professional), ECDL ImageMaker. Based on the recommendations of the Agency for Science and Higher Education in November 2014, the Faculty of Philosophy should strive for a new method of learning and teaching and become recognizable as a center of excellence (Legčević, Hećimović, 2016). Additionally, there is a tendency to change the methodological approaches used in teaching, primarily from transition from traditional lectures to active learning, improved e-learning e-learning, and the ability to direct the Philosophy faculty's activities to new target groups of future students.

The alignment of the study program with the strategic goals of the Faculty of Philosophy is recognized in the strategic goals through the teaching process, scientific and research and international work, the system of improvement and in the developmental and professional work, especially for the development of human resources (informing and sensitizing teachers and students for e-learning). The communication technologies in teaching and e-learning development is one of the key tasks of the program by which the Faculty of Philosophy would be recognized as a center of excellence, which belongs to the specific objectives of the FFOS Strategy. It also means to ensure the transfer of research outcomes and new knowledge into educational programs, dissemination, publication and application of research results to community wellbeing, understanding and mastering social processes and the risks that new technologies bring them, global economic development, demographic structure change, and increased complexity of contemporary management societies.

\section{Research Methodology}

Educational technology should not be primarily seen as a technical tool but as an aesthetic and symbolic material for self-expression and communication. Although some complain that knowledge, which is adopted and mediated through electronic media, lacks consistency, homogeneity and that is not permanent, it is attractive to students. The reasons are simple: attractive visual information, dynamic forms and active and interactive communication. A good example of the successful use of technology in teaching is on-line education that relies on the use of technology, including different forms of multimedia learning, especially in learning a foreign language. Verduin and Clark (1991) define on-line education with the following elements: a) temporal and spatial separation of students and teachers during most of the educational process of using educational media (Internet, etc.), for the purpose of connecting students and teachers and for presenting educational content, b) providing two-way communication between students and teachers, institutions or organizations which conducts education, and c) the emphasis on students mastering the concepts at their own pace. There are currently 30 different 
courseware tools available on the market, and some of the most popular are: WebCT (Web Course Tools), TopClass, Lotus Learning Space and Webfuse. Due to the fact that the technology is the main medium for transmission of educational content, to make the teaching process more successful it is necessary for students and teachers to be familiar with the use of technology. Digital media, interesting and close to students by the way of thinking can be a great tool for moving towards higher learning levels - comprehension, implementation, analysis, synthesis and evaluation (self-evaluation):

- It is necessary to classify media by the type and purpose (television, print media, audio-visual, electronic, etc.).

- The team work and media workshops where the parents would be invited to participate together with children are also recommended.

- It is important to become aware that relationship between school and media can be changed by the use of certain media content.

- It is advisable to integrate precisely defined learning outcomes in advance for the development of media education (Moser, 2007).

Tasks of the research result from the research objectives. In this study, the following tasks of the research are:

- With the use of self-assessing of the frequency of use of digital technology of the respondents at higher education institutions to determine the representation of information and communication technologies through the course syllabus that are directly associated with the development of computer literacy and change of the educational paradigms.

- Analyze the frequency of application of modern technology in the classroom with different majors' faculties that could have an impact on the development of digital competence and use the level of analysis to determine the necessity of implementation of the program Multimedia training and e-learning at those faculties where there will be shown a low level of digital competence.

- Analyze the opinions of the respondents who had experience in online collaborative learning where there will be shown greater willingness on the application of technological implications as the antipode to the development of new paradigms.

- Analyze the differences in opinion of respondents with connection between agreement on the purpose of teaching methods, didactic system of teaching, and frequency of use thereof.

For realization of set tasks, the research requires the following tasks:

- Determine whether there is an impact of scientific areas and universities, on which the teachers and associates work, on the level of self-assessment of their digital competence

- Determine the way of forms of education and development of digital competence for a change of educational paradigms in teaching

- Determine the frequency of the application of new technologies among the respondents of different scientific fields

- Through the correlation matrix determine the impact of variables in research on the level of knowledge in the components of the application of teaching methods

- Determine the impact factor - experience in online collaborative learning in the components of the application of technological implications for changing educational paradigms in teaching with students. 


\section{Research hypotheses}

The paper presents the following affirmative six $(\mathrm{H} 6)$ hypotheses that are complementary to the subject matter and methodology of the text.

$\mathrm{Hl}$ - There is a difference between the scientific field and the universities where teachers and associates work and the level of self-assessment of their digital competences.

$\mathrm{H} 2$ - There is a difference between respondents in the self-assessment of the frequency of use of digital technology for reading professional and scientific literature for the purpose of application of new educational paradigms in teaching.

H3 - Respondents who are members of the digital generation show a greater degree of use of ICT in teaching and application of the teaching methods.

$\mathrm{H} 4$ - Respondents who apply e-learning in the classroom by using different ESystems (MOODLE) and who have already had experience in online collaborative learning are more likely to apply technological implications as the antipode to the development of new educational paradigms.

$\mathrm{H} 5$ - There is a difference between respondents in the self-assessment on the use of various forms of ICT in the teaching process by participating in online collaborative teaching and using mixed learning in the teaching process.

H6 - There is a difference between respondents in the connection between agreement on the claims of teaching methods and didactic system of teaching and the frequency and reason for using technology to change educational paradigms.

Tasks of this research result from the research objectives. In this study, the following tasks of the research are:

1. With the use of self-assessing of the frequency of use of digital technology of the respondents at higher education institutions to determine the representation of information and communication technologies through the course syllabus that are directly associated with the development of computer literacy and change of the educational paradigms.

2. Analyze the frequency of application of modern technology in the classroom with different majors' faculties that could have an impact on the development of digital competence and use the level of analysis to determine the necessity of implementation of the program Multimedia training and e-learning at those faculties where there will be shown a low level of digital competence.

3. Analyze the opinions of the respondents who had experience in online collaborative learning where there will be shown greater willingness on the application of technological implications as the antipode to the development of new paradigms.

4. Analyze the differences in opinion of respondents with connection between agreement on the purpose of teaching methods, didactic system of teaching, and frequency of use thereof.

For realization of set tasks, the research requires the following tasks:

- Determine whether there is an impact of scientific areas and universities, on which the teachers and associates work, on the level of self-assessment of their digital competence

- Determine the way of acquiring new knowledge and forms of education that contributes to the acquisition of digital competence for a change of educational paradigms in teaching

- Determine the frequency of the application of new technologies among the respondents of different scientific fields 
- Through the correlation matrix determine the impact of variables in research on the level of knowledge in the components of the application of teaching methods

- Determine the impact factor - experience in online collaborative learning in the components of the application of technological implications for changing educational paradigms in teaching with students.

\section{Data and methods}

The study was conducted on a representative sample $(N=1800)$ of teachers and associates of higher education institutions in Republic of Croatia 1 1,000 out of the 15,000 employees in the system of science and higher education) among the various constituents (faculties and departments), in Osijek ( $N=720,40 \%$ ), split ( $N=$ $594,33 \%)$, and Zagreb ( $N=486,27 \%)$. The stratified sampling was conducted of the population of teachers and associates in higher education institutions. This study is part of a wider research on determining the level of knowledge of digital competence and frequency of application of modern technologies in teaching of higher education teachers and associates of Europe, which was conducted in the framework of DFGP project "E-Learning und Multimediakompetenz der Deutschen Initiative für Netzwerk Information". Online research was conducted in the period from April 2, 2015, to June 14, 2015. Online questionnaire was on the web front pages of individual components of universities. For this purpose, an extensive questionnaire that was implemented was drawn up by experts (media psychologists) at the University of Johannes Guttenberg launched within the common European project. Of the total 1,800 respondents, 990 are of female ( $N=55 \%$ ) and 810 of male gender $(\mathrm{N}=45 \%)$. The average age of the respondents at the time of the test ranged from 35 to 58 years. What is presented in this paper are the most important results of the research regarding the use of ICT in the classroom and working with students. The first eight general information questions related to the set variables (gender, name of the university - a component, place of residence, teaching experience, location of the university, scientific field, and vocation). The second part of the online questionnaire consisted of nineteen questions where respondents assessed their own level of knowledge of digital competence. It explored the affiliation to digital generation, the frequency of using new educational paradigms in teaching that can contribute to the development of digital competence for a change of paradigms in teaching, the impact of factors - affiliation to generation in the components of the digital generation, and application of ICT in teaching. Students assessed on a scale of four levels (1 - never, 4 - often). In the questions where respondents evaluated the frequency of use of new technologies there were seven options to choose from: daily, several times, once a week, several times a month, once a month, less than once a month, I do not use the new technologies for work and school. In matters where there was the and an opinion on the importance of teachers to work with new media, and the purpose of the use of modern technology in the classroom as well as for change of educational paradigm respondents were choosing on a scale of one to five (1-completely disagree, 5- completely agree). In matters related to assessment of knowledge, the participants were able to choose among the five offered answers: excellent, very good, good, bad, very bad. Procedures for data processing were descriptive and inferential statistics, namely the process of calculating the frequency, percentage, Chi-square $(x 2)$ test, and the correlation coefficient (Cramer's $\vee(\rho c)$ coefficient). 


\section{Results and discussion}

The most common respondents, given the place of employment of universities in the Republic of Croatia, were employees of the components of the University of Osijek $(\mathrm{N}=40 \%$ ): Faculty of Humanities and Social Sciences, Faculty of Education, Faculty of Electrical Engineering, Faculty of Economics, Department of Cultural Studies, Faculty of Food Technology, and Faculty of Law; from the University of Zagreb ( $N=$ 27\%): Faculty of Humanities and Social Sciences, Faculty of Physical Education, Faculty of Law, Faculty of Architecture, Faculty of Economics; from the University of Split ( $N=33 \%$ ): Faculty of Arts, Faculty of Law, Faculty of Economics, Academy of Arts, Faculty of Medicine, Faculty of Education, Faculty of Chemical Engineering and Technology, and Faculty of Electrical Engineering. The response rate is higher in the younger population using the web than it is which is the case with other respondents who sometimes use it.

According to the results of the chi-square test $(\lambda 2)$ statistically significant difference depending of the age $\left(x^{2}=32.9\right.$, $\left.\mathrm{df}=3, \mathrm{p} \leq 0.0001\right)$ and gender of the respondents $\left(x^{2}=36.0, d f=1, p \leq 0.0001\right)$ who participated in the survey, where respondents aged $35-45$ years ( $N=52.14 \%)$ were significantly more engaged in online testing in relation to the age group $55-65$ years $(\mathrm{N}=8 \%)$. Thus, respondents who are aged 35-45 years and filled out the questionnaire were probably more motivated because research has proven that they had a higher level of digital competence in completing questionnaires unlike those respondents aged 55-65 years. Therefore, respondents with higher levels of already adopted digital competence, often filled online-questionnaire. The study showed $36.78 \%$ of subjects in the vocation of assistant professor, aged 35-45 years, as clearly shown in Table 1, who considered themselves members of the digital generation, and thereby assessed their level of digital competence higher compared to those of higher vocations, associate ( $N=4.23 \%$ ) and full professors ( $N=2.45 \%$ ), aged $55-65$ years, who feel that they do not belong to the digital generation. In other words, younger respondents actively use ICT in everyday life which makes their level of digital competence higher.

Table 1 Prevalence of subjects by profession, scientific area, and affiliation to digital generation

\begin{tabular}{|l|r|r|l|r|r|}
\hline \multicolumn{1}{|c|}{ Vocation } & $\begin{array}{c}\text { Prevalence } \\
\text { (\%) }\end{array}$ & $\begin{array}{c}\text { Affiliation to } \\
\text { (non) digital } \\
\text { generation (\%) } \\
\text { in relation to } \\
\text { prevalence }\end{array}$ & Scientific area & $\begin{array}{c}\text { Affiliation to } \\
\text { (non) digital } \\
\text { generation (\%) } \\
\text { in relation to } \\
\text { prevalence }\end{array}$ & $\begin{array}{c}\text { Prevalence } \\
\text { (\%) }\end{array}$ \\
\hline $\begin{array}{l}\text { Lector/ lecturer/ } \\
\text { professional } \\
\text { associate }\end{array}$ & $14.95 \%$ & $9.56 \%$ & Natural Sciences & $3.9 \%$ & $4.5 \%$ \\
\hline Assistant & $27.6 \%$ & $21.6 \%$ & $\begin{array}{l}\text { Technical } \\
\text { Sciences }\end{array}$ & $14.56 \%$ & $19.89 \%$ \\
\hline $\begin{array}{l}\text { Assistant } \\
\text { professor }\end{array}$ & $36.78 \%$ & $22.36 \%$ & Social Sciences & $21.21 \%$ & $43.69 \%$ \\
\hline $\begin{array}{l}\text { Associate } \\
\text { professor }\end{array}$ & $10.3 \%$ & $4.23 \%$ & Humanities & $22.36 \%$ & $34.39 \%$ \\
\hline Full professor & $8.2 \%$ & $2.45 \%$ & $\begin{array}{l}\text { Biomedicine and } \\
\text { Health Care }\end{array}$ & $2.3 \%$ & $5.53 \%$ \\
\hline $\begin{array}{l}\text { Full professor } \\
\text { with permanent } \\
\text { appointment }\end{array}$ & $2.1 \%$ & $0.9 \%$ & Other & $0.3 \%$ & $2 \%$ \\
\hline
\end{tabular}

Source: Authors. 
As far as the assessment of the digital competence of the entire sample of respondents most respondents statistically significant estimate their digital competence as very good ( $N=36.78 \%$ ) or excellent ( $N=35.06 \%)$. That is, over $70 \%$ of respondents believe that they are competent when it comes to the use of computers and new technologies. These figures can be explained by the fact that the technology is present all around us and the society considers the knowledge of the use of ICT as something normative.

If the responses from all respondents in terms of profession or status of the respondents are analyzed, the results show that the subjects of smaller titles or statuses, for example, assistants and lecturers, and assistant professors are considered to belong to the so-called digital generation ( $\mathrm{N}=65.56 \%$ ) and during their training in the profession (workshops, postgraduate doctoral studies, and the like) had represented courses or representation of ICT which are associated with the development of digital competence.

Also, research has shown that factors results in a group of respondents - members of the digital generation who participated in the study - $76.35 \%$ of them own a personal computer, tablet, other types of innovative technologies such as an e-book reader and so on, while $23.65 \%$ of respondents who consider themselves to be in non-digital generation were larger, and those who are at higher academic titles, do not have digital tools. Thus, knowledge of the use of ICT requires continuous training via various tools, while those who do not possess knowledge of ICT have no need for digital tools.

When compared to the results in terms of scientific areas, the majority of respondents $(x 2=717.32$, $d f=3, p<0.05)$ of humanities and social sciences, and biomedicine and health consider themselves to have a general level of digital competences, which means the ability to use Microsoft Office - system ( $\mathrm{N}=46.25 \%$ ), and not the professional level such as skills in e-tools, innovative software like the program Team Viewer, and the like. There was a statistically significant difference and significant correlation between universities in Osijek and Zagreb, which have contributed to the development component of digital competence for research with regard to the representation of computer programs at home $\left(X^{2}=112.12\right.$, df $=3$, $\mathrm{p} \leq 0.05$, Cramers $\mathrm{V}=.18$ ).

The research got the result that the assistants from surveyed universities who have not yet acquired the academic title more often use the Internet for scientific research and for teaching than those who have gained academic title. Thus, younger respondents are more likely to use ICT because during their schooling the ICT were simultaneously developing which allowed the respondents to have contact with ICT from an early age, which is why they think of the Internet as an advantage in their work. There is a statistically significant difference and a slight correlation between the frequency of use of digital technology for reading professional and scientific literature in one year for the purpose of application of new educational paradigms in teaching $\left(X^{2}=112.12\right.$, $d f=6, p \leq .05$, Cramers $V=$. 17). That is, respondents who frequently use digital technology to read scientific literature often implement new teaching model. The data indicates on Figure 1. 


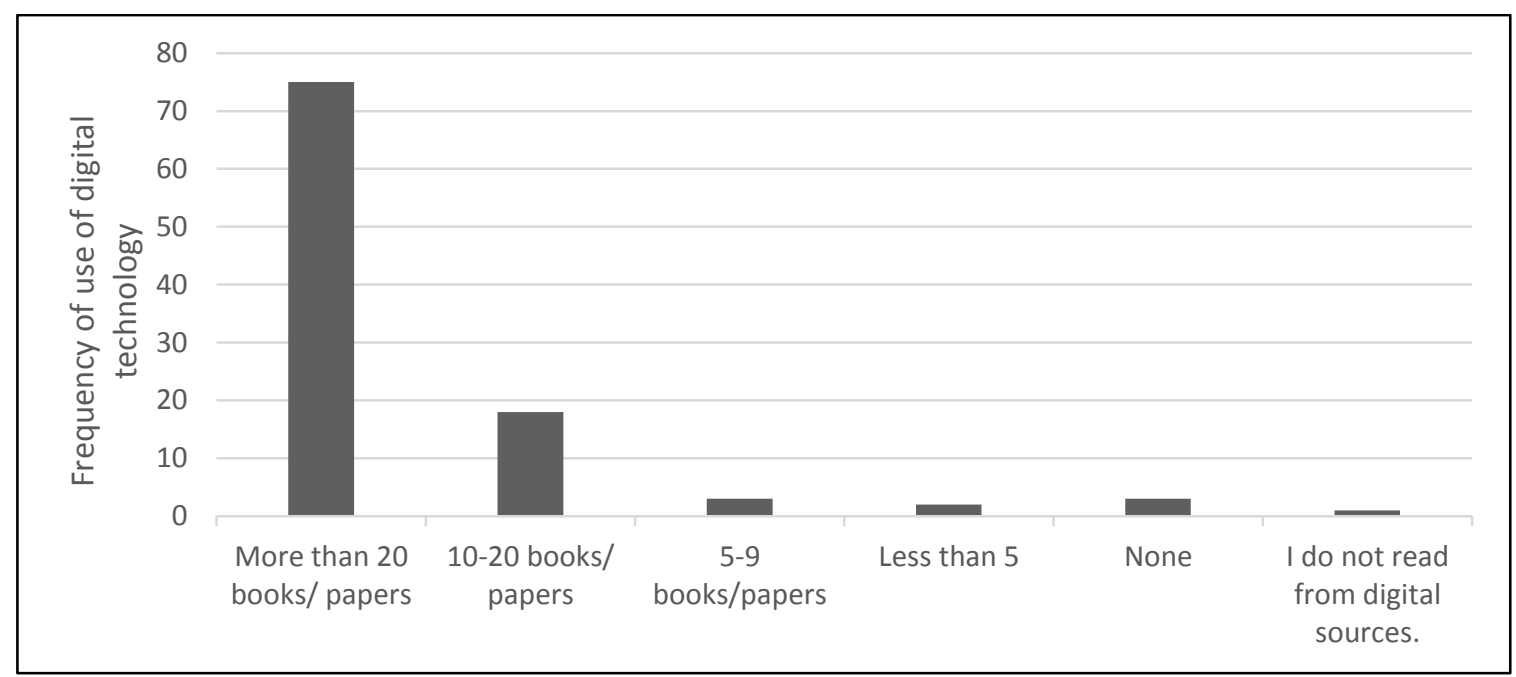

Figure 1. Assessment of the frequency of use of digital technology for reading professional and scientific literature in one year

Source: authors.

The study showed that in the assessment of knowledge in the field of application of technology of e-learning in the classroom, for example, MOODLE system, results show that there is a significant difference in the application of e-learning $(x 2=$ 502.85, $\mathrm{df}=4, \mathrm{p}<0.05$ ), and that the majority of respondents very well implement MOODLE in their teaching (Figure 2). Using MOODLE in teaching helps students and respondents to improve the use of e-tools in teaching. Although, the results show that the respondents of technical sciences ( $N=56.8 \%)$ and the humanities ( $N=42.5 \%$ ) use more MOODLE in teaching than those of Social Sciences ( $N=39.6 \%$ ). There was a statistically significant difference and slight association between respondents who work in technical sciences from the University of Split and University of Osijek with frequent use of MOODLE in teaching ( $x 2=139.12$, $\mathrm{df}=2, \mathrm{p}<0.05$, Cramers $\mathrm{V}=.19$ ). Also, research has shown results that respondents state ( $N=73.2 \%$ ) that they usually use modern technology in the presentation of results and tasks, enabling the methodical change of the teaching classes ( $N=66.1 \%)$, making creative tasks ( $N=$ 63.6\%), improving outcomes of learning ( $\mathrm{N}=62.5 \%)$, the transfer of current information ( $N=61.8 \%$ ), and a slightly smaller percentage states that they use modern technology in the promotion of the creative work ( $N=60.7 \%$ ), better communication among colleagues and students ( $\mathrm{N}=60.7 \%$ ), implying new learning environments $(53.6 \%)$ as well as facilitating the evaluation of learning $(46.4 \%)$. Research points at the fact that $61.25 \%$ participated in online collaborative teaching.

However, a statistically significant difference between respondents in the University of Split considering the University of Osijek, that respondents in Osijek were more likely to participate in online collaborative teaching and those were respondents who are of lower and higher rank $\left(X^{2}=104.12\right.$, df $=5, p \leq .0 .05$, Cramers $V=.14)$; and that there was no statistically significant difference between the respondents from the University of Osijek and Zagreb in relation to the same variable $\left(X^{2}=95.12, d f=3, p \geq 0.05\right.$, Cramers $\left.V=.12\right)$. Correlation analysis shows that the largest associations were observed between participation in online collaborative teaching with the use of mixed learning in the teaching process $(r=.44, p \leq 0.05)$. Figure 2 . indicates the fact that only $43.25 \%$ of all respondents use various forms of ICT in the teaching process. This data is also very worrying, especially when there is a significant difference between subjects from the University of Zagreb as opposed to 
the University of Osijek that respondents with the title of assistant professor at the University of Zagreb, which often use ICT in the teaching process as opposed to the University of Osijek ( $X^{2}=102.12, \mathrm{df}=4, \mathrm{p} \leq 0.05$, Cramers $\left.V=.13\right)$; and that there was no statistically significant difference between the respondents from the University of Split and Osijek related to the same variable $\left(X^{2}=91.12\right.$, df $=4, p \geq 0.05$, Cramers $\vee=$ .12). Correlation analysis shows that the largest associations were observed between the frequency of use of ICT in the teaching process and in participating in online collaborative teaching with the use of mixed learning in the teaching process $(r=$ .44, p $\leq 0.05$ ), and in respondents as an assistant, lector, and senior assistant or PostDoc. Furthermore, there is a significant difference between respondents from the University of Osijek and Split in the self-assessment on the use of various forms of ICT in the teaching process by participating in online collaborative teaching and the use of mixed learning in the teaching process $\left(X^{2}=102.12\right.$, df $=5, p \leq 0.05$, Cramers $V=$ .15) (see Figure 2). Thus, respondents who used different e-tools in the online collaborative teaching frequently applied mixed learning and agree with the statement that the common use of innovative E-Systems in teaching changes the traditional forms of teaching in the so-called new model, learning forward collaborative teaching.

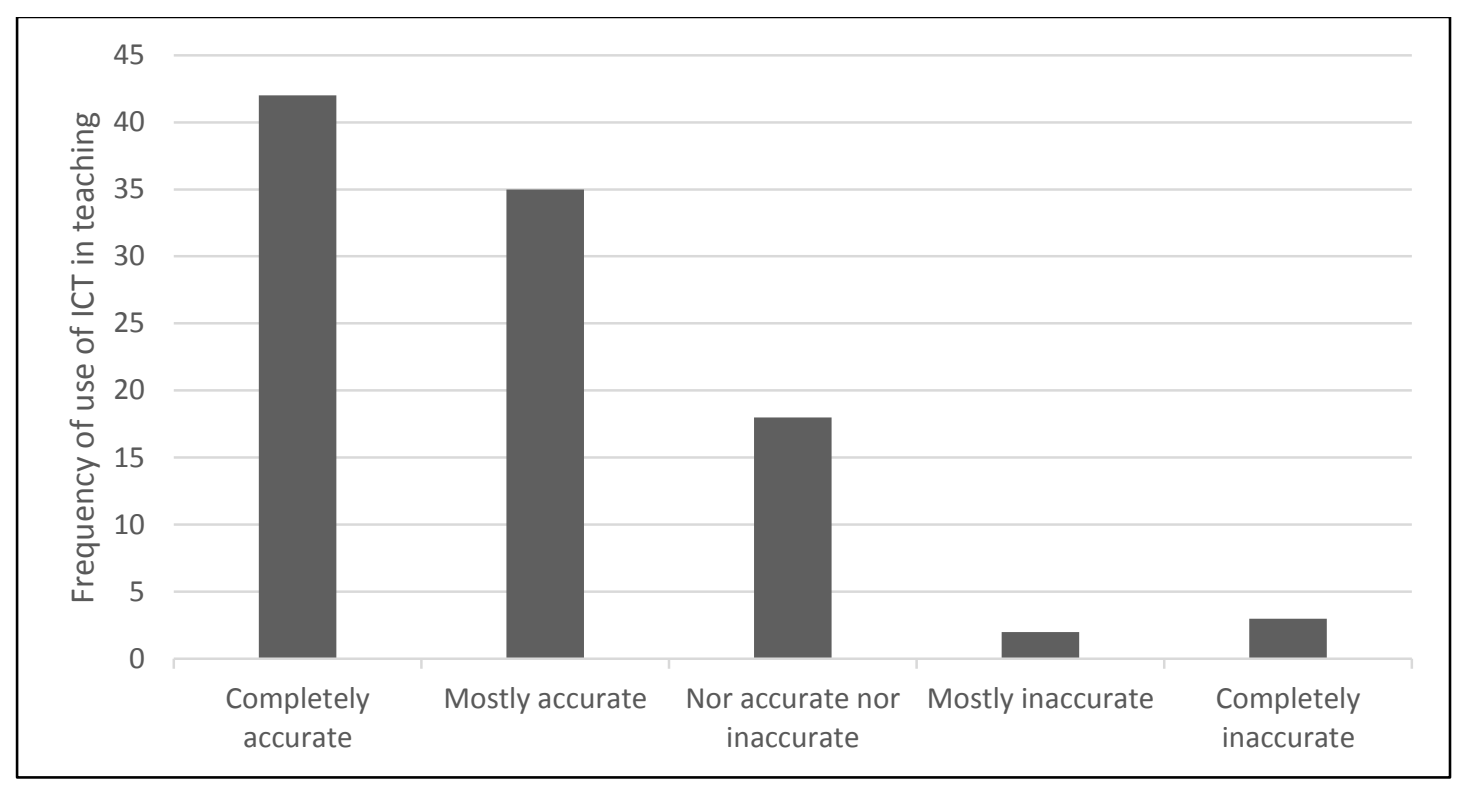

Figure 2 Self-assessment of the respondents about the use of various forms of ICT in

Source: authors the teaching process

Table 2 shows statistically significant differences and connections in the level of each of these claims that are mentioned in the table in relation to the frequency and purpose of using the media to change the educational paradigms. The following are significant differences and high correlations among claims: methods of active learning and in improving learning outcomes ( $r=.787852,5911, p \leq 0.05)$, a method of practical work and providing methodological change of teaching $(r=$ $.634512,6.521, p \leq 0.05)$, and the hybrid-cooperative learning and the implications of new learning environments $(r=.413426,5521, p \leq 0.05)$. 
Table 2 Correlation between the claims of the use of teaching methods, didactic system of teaching with the purpose, and frequency of use of technology in teaching

\begin{tabular}{|c|c|c|c|}
\hline $\begin{array}{c}\text { Teaching methods and didactic } \\
\text { teaching systems }\end{array}$ & Correlation & Chi-square & $\begin{array}{l}\text { The frequency and } \\
\text { purpose of using new } \\
\text { media to change the } \\
\text { educational paradigm }\end{array}$ \\
\hline $\begin{array}{l}\text { 1. Social forms of learning activities: } \\
\text { collaborative learning } \\
\text { (cooperative learning) }\end{array}$ & 0.364569 & $4.951, p \leq .05$ & $\begin{array}{l}\text { In the presentation of } \\
\text { results and tasks }\end{array}$ \\
\hline 2. Active learning methods & 0.787852 & $5.911, p \leq .05$ & $\begin{array}{l}\text { To improve learning } \\
\text { outcomes }\end{array}$ \\
\hline $\begin{array}{l}\text { 3. Mutual relations of teaching } \\
\text { methods }\end{array}$ & 0.459357 & $3.251, p \leq .05$ & $\begin{array}{l}\text { In facilitating the } \\
\text { evaluation of learning } \\
\text { outcomes }\end{array}$ \\
\hline 4. Methods of practical work & 0.634512 & $6.521, p \leq .05$ & $\begin{array}{l}\text { In providing } \\
\text { methodological } \\
\text { changes in teaching }\end{array}$ \\
\hline 5. Hybrid-collaborative learning & 0.413423 & $5.521, p \leq .05$ & $\begin{array}{l}\text { Implication of new } \\
\text { learning environments }\end{array}$ \\
\hline 6. Traditional teaching & 0.234736 & $3.251, p \leq .05$ & $\begin{array}{l}\text { Transmission of } \\
\text { information, not } \\
\text { knowledge }\end{array}$ \\
\hline 7. Method of oral conversation & 0.436512 & $4.951, p \leq 0.05$ & $\begin{array}{l}\text { In promoting the } \\
\text { creativity of students }\end{array}$ \\
\hline $\begin{array}{l}\text { 8. Train teachers to work with new } \\
\text { media in the classroom }\end{array}$ & 0.451236 & $3.235, p \leq .05$ & $\begin{array}{l}\text { For better } \\
\text { communication among } \\
\text { colleagues and students }\end{array}$ \\
\hline 9. Mentorship teaching & 0.741232 & $6.251, p \leq .05$ & $\begin{array}{l}\text { For creation of creative } \\
\text { tasks }\end{array}$ \\
\hline 10. Problem solving teaching & 0.234152 & $4.131, p \leq .05$ & $\begin{array}{l}\text { Development of: text, } \\
\text { photography, records, } \\
\text { posters, digital projector }\end{array}$ \\
\hline 11. Individual students work & 0.512321 & $2.151, p \leq .05$ & $\begin{array}{l}\text { Photography, film, DVD } \\
\text { player, video cameras }\end{array}$ \\
\hline 12. Programmed learning & 0.62156 & $3.151, p \leq .05$ & $\begin{array}{l}\text { Computer, formatting } \\
\text { texts, spreadsheets, } \\
\text { browsing the Internet, } \\
\text { online exercises, } \\
\text { webinars }\end{array}$ \\
\hline
\end{tabular}

Source: Authors.

\section{Conclusions}

Media use in a teaching process occurs in several forms. It is used as a work equipment and teaching aid, as well as a tool or a curriculum unit. This specifically means that students are learning with the help of the media, individually or in groups. It also means that teachers are planning their lessons for students to use technology in a self-inquiry based manner, as well as students express their creativity in producing technology-based lesson outcomes, while learning about the new technology.

Considering these advantages of technology use, it is necessary to speak about digital logic and algorithmic thinking (which takes place with the use of media as a teaching subject). It is important to explore how to enable students to incorporate the use of media and new technologies in educational purposes, especially in research on the introduction of new educational paradigms in the curriculum of teaching. 
The research confirmed the hypothesis $\mathrm{Hl}$ that there is a difference between the scientific field and the universities at which the teachers and associates work, and the level of self-assessment of their digital competence, and confirmed the hypothesis $\mathrm{H} 3$ that respondents who are members of the digital generation show a greater use of ICT in teaching and greater application of ICT in teaching methods. The use of different instructional and learning methods is important in building students' skills and assures their mastery of the concepts (European educational tradition has been led by the premise based on "pedagogy of success for all"). Furthermore, the problem of "stagnant knowledge", which is usually recognized and disapproved of in our educational system, cannot be solve with the continued use of the old-fashioned, lecturing-style teaching, which students find dull and boring. . Digital media is interesting to the new-age students, and it is close to their "way of thinking" (hence the students are referred to as "digital natives", fluent "speakers" and digital technology users. Such digital interest and literacy can be a great tool for moving towards "higher" learning levels comprehension, implementation, analysis, synthesis and self-evaluation. A good example of the successful use of technology in teaching is on-line education that relies on the use of technology, including different forms of multimedia learning, especially in learning a foreign language. It is precisely this lack of research, but also the motivation for future research to show how new technologies can help in higher education for learning and foreign language. The data also confirmed the hypothesis $\mathrm{H} 2$ that there is a difference between respondents in the self-assessment of the frequency of use of digital technology for reading professional and scientific literature for the purpose of application of new educational paradigms in teaching. Hypothesis $\mathrm{H} 4$ is also confirmed where it was shown that subjects who applied elearning in the classroom by using different E-Systems (MOODLE) and who have already had experience in online collaborative learning are more likely to apply technological implications as the antipode to the development of new educational paradigms.

The analysis of the level of digital literacy and the impact factor of experience in the participation of the respondents in the online collaborative teaching and experience in the use of mixed learning in the educational process; the necessity of implementation of Multimedia training and e-learning was determined at those faculties where there was a low level of digital competence as an antipode to the development of the application of new educational paradigms in teaching. With that, the hypothesis $\mathrm{H} 5$ is confirmed.

By analyzing the difference between respondents in the connection between agreement on the claims of teaching methods, didactic teaching system, the frequency and purpose of using new media to change the educational paradigms, the hypothesis $\mathrm{H} 6$ is confirmed.

The research confirmed the hypothesis $\mathrm{Hl}$ that there is a difference between the scientific field and the universities at which the teachers and associates work, and the level of self-assessment of their digital competence, and confirmed the hypothesis $\mathrm{H} 3$ that respondents who are members of the digital generation show a greater use of ICT in teaching and greater application of ICT in teaching methods. The data also confirmed the hypothesis $\mathrm{H} 2$ that there is a difference between respondents in the self-assessment of the frequency of use of digital technology for reading professional and scientific literature for the purpose of application of new educational paradigms in teaching.

Hypothesis $\mathrm{H} 4$ is also confirmed where it was shown that subjects who applied elearning in the classroom by using different E-Systems (MOODLE) and who have 
already had experience in online collaborative learning are more likely to apply technological implications as the antipode to the development of new educational paradigms. However, the research constraints have been based on how to motivate teachers to solicit online questionnaires as well as to examine completely the digital skills including their online generation.

The analysis of the level of digital literacy and the impact factor of experience in the participation of the respondents in the online collaborative teaching and experience in the use of mixed learning in the educational process; the necessity of implementation of Multimedia training and e-learning was determined at those faculties where there was a low level of digital competence as an antipode to the development of the application of new educational paradigms in teaching. With that, the hypothesis $\mathrm{H} 5$ is confirmed. By analyzing the difference between respondents in the connection between agreement on the claims of teaching methods, didactic teaching system, the frequency and purpose of using new media to change the educational paradigms, the hypothesis $\mathrm{H} 6$ is confirmed. Media education should be oriented, directed, and lead by these basic principles. Relevant, self-determined, creative, and socially responsible action and behaviour influenced by the media is related to certain conditions: life situation and communicative environment of teachers and students, their needs and emotions, their knowledge and experience, as well as the level of their ability to judge symbolic values. Where media reach and grow as a means of information, influence, entertainment, education, and the organization of everyday life, that they become the subject of media education. The use of media in everyday life, the need to acquire media competence and the importance of media activity should be directed towards the symbolic exchange between the recipient and the media. While, on the one hand, opening unlimited possibilities of effective cooperation between students and teachers, access to information and lifelong learning, on the other hand, are not only observed primarily as a technical tool in the educational process, but as an aesthetic and symbolic material for self-expression and to improve the quality of communication. Based on the analysis set (four) null hypothesis, none of which has not been accepted, accepting the second hypothesis, according to which teachers.

\section{References}

1. Adomeit, K. (1997). Hochschulreform und was nun? Berichte- Glossen Perspektiven. Ullstein Buch, Berlin.

2. Ashaver, G. (2004). Handbuch des audio-visuellen Lehrens und Lernens. Deutscher Sparkassenverlag.

3. Commission of the European Communities (2007). Improving the Quality of Teacher Education. Available

at http://www.europarl.europa.eu/RegData/docs_autres_institutions/commission_europeenn e/sec/2007/0931/COM_SEC\%282007\%290931_EN.pdf [4 June 2018].

4. Farke, G. (2006). OnlineSucht - Wenn Mailen und Chatten zum Zwang werde. Kreuz Verlag, Stuttgart.

5. Jovanović, Ž., Zelenika, S. (2013). Science and higher education in Croatia at the verge of entering the EU. Periodicum Biologrum, Vol. 115, No. 1, pp. 27-31.

6. Legčević, J., Hećimović, V. (2016). Internal quality assurance a higher education institution. Poslovna izvrsnost, Vol. 10, No. 2, pp. 75-86.

7. Moser, H. (2007). Einführung in die Medienpädagogik: Aufwachsen im Medienzeitalter. Leske und Budrich, Opladen.

8. Rychen, L., Salganik, M. (2000). Key Competencies for a Successful Life and WellFunctioning Society. Hogrefer \& Huber Publisher, Cambridge, USA. 
9. Verduin, J., Clark, T. (1991). Distance Education - The Foundations of Effective Practice. Jossey-Bass, San Francisco.

\section{About the authors}

Mirela Müller has been Assistant Professor at University of Osijek, Faculty of Humanties and Social Sciences. Areas of scientific interest: Distance learning, multimedia didactics, media pedagogy, media semiotics and sociolinguistics, media socialization and culture, philosophy of symbolic forms, prevention of addiction-modern media manipulation, Modern technologies in foreign language learning, semantic difference and etiological analysis, European dimension of education. She can be contacted at: mtolic@ffos.hr.

Ines Begović is a student, Univ. bacc. philol. angl. et univ. bacc. paed., Department of Pedagogy, Faculty of Humanities and Social Sciences, University of Osijek. She can be contacted at: ines-vk@live.com.

Ralf Baumgärtner is a postdoctoral student at the University of Mainz, Institute of Media Education, Germany. He was born in Mannheim, Germany. He specializes in the field of media research in the area of semantic differentiation and statistics. He can be contacted at: rbaumgartner45web.de. 